\title{
The Usage of Social Media and E-Reputation System in Global Supply Chain: Comparative Cases from Diamond \& Automotive Industries
}

\author{
Mostafa Mohamad1', Mohammed Ali², Abdullah Sultan Abdullah'1, Al Shimaa Elfiky ${ }^{3}$ \\ ${ }^{1}$ Salford Business School, University of Salford, Manchester, UK \\ ${ }^{2}$ Alliance Manchester Business School, University of Manchester, Manchester, UK \\ ${ }^{3}$ ADNEC Corporation, Abu Dhabi, UAE \\ Email:m.r.a.mohamad@salford.ac.uk
}

How to cite this paper: Mohamad, M., Ali, M., Abdullah, A.S. and Elfiky, A.S. (2018) The Usage of Social Media and E-Reputation System in Global Supply Chain: Comparative Cases from Diamond \& Automotive Industries. Int. J. Communications, Network and System Sciences, 11, 69-103. https://doi.org/10.4236/ijens.2018.115006

Received: March 30, 2018

Accepted: May 26, 2018

Published: May 29, 2018

Copyright $(9) 2018$ by authors and Scientific Research Publishing Inc. This work is licensed under the Creative Commons Attribution International License (CC BY 4.0).

http://creativecommons.org/licenses/by/4.0/

\begin{abstract}
The last decade witnesses a heave use of social media-based information systems in different fields of business such as logistics, procurement, and supply chain management. Managing these types of information systems, could help companies to outsource their supply chain functions in a global scale and enhance their competitive advantages. However, the digital performance of these activities inherent risks of inappropriate supplier selection, lack of trust, bounded rationality and uncertainty about the supply conditions (e.g., pricing, shipping and timing). To address such challenges, this research explains how companies use e-reputation systems and social media to select their global trusted suppliers. Based on two-case evidence from British Diamond and Egyptian Automotive companies, the researchers conducted 20 interviews with purchasing and supply chain professionals. Chen \& Lin's reputation system model has been adopted to explain the process of selecting and evaluating a trusted supplier and to inform our data analysis. Our findings referred to the lack of experience among diamond professionals on how to use e-reputation systems and their lack of understanding to the role of social media-based ratings or referrals during the stages of selection suppliers' discovery and approval. Though, automotive professionals find e-reputation system a strong tool to build goodwill, tacit credibility, competence and predictable trust. Ironically, both cases confirm that supply chain professional use these systems to re-evaluate and reselect their existing suppliers than to extend new supply networks.
\end{abstract}

\section{Keywords}

E-Reputation Systems, Social Media, Global Supply Chain 


\section{Introduction}

The propagation of ICT has a pivotal role in the growth of global supply chain. Due to a need to save costs and to deliver products to market more quickly, more and more companies outsource their supply chain functions [1] [2]. However, failure to take an adequate care in selection of new partners is considered as a main barrier of global supply chain [3]. In the traditional supplier selection, companies build the trust based on characteristics such as capabilities and competence of their partners [3]. In the absence of direct experiences, the partner will be selected based on limited information about self-proclaimed competences provided by the parties themselves. Thus, trust plays a significant role in selecting suppliers among global supply chain partners. Lack of trust is a main barrier to establishing a global supply chain.

In global supply chains, due to a lack of direct experiences, there is uncertainty regarding the reliability of suppliers, as well as the products and services they offer. Reputation systems are one of the established mechanisms to help companies to select their global trusted suppliers. In fact, reputation systems have been proven to be an effective tool to attract different partners in building new business to business relationships and to play a role in their partner selection processes [4]. In addition to e-commerce websites, social media provide a platform for business customers to rate their suppliers and reflect on their own experience with outsourced outputs [5]. Since companies have to trust an anonymous individual and potentially unreliable information sources, it can be seen that companies are not only hesitant to trust suppliers but also reputation systems.

The literature on Supply Chain Management (SCM) went through different approaches. [6] discusses areas of strategic operations and logistics management. Other scholars such as ([7], p. 698) set a detailed taxonomy of SCM across three disciplines: 1) methods and processes of SCM; 2) problem solving to supply chain problems; and 3) performance measurement of supply chain strategies. A common issue between the aforementioned approaches is how to improve trust in supply chain partners. The relationship between the efficient outsourcing and effective SCM has been proven as significant in theoretical studies like [8] [9] and empirical research such as [10]. The outsourcing process differs from one company to another and aims to achieve different goals. Some studies refer to cost reduction and short lead time [8]; whilst others argue that outsourcing enhances the bargaining power [11]. However, there is no clear guide of how these different goals require different outsourcing processes and decision-making methodology [12].

In the field of digital supply chain, [4] adopted a quantitative reputation model based on diameters such as: organization definition, Agent, Roles as Organisational Mechanisms, Dynamics (in between agents, roles and action), Organisational Norms, and Personal Norms. [13] argues that 30\% of suppliers publish fake ratings. He set a reputation system that mixed the price and the sales track 
record of the seller with the charges he has already paid into the system. In doing so, it becomes too expensive and time consuming for the liars who may collude to organize an attack discrediting a commercial platform.

In addition to the theoretical side of the problem, there is an empirical side. The United Nations Information Economy Report 2010 reported that 25\% of published data about business suppliers are not true and the rest have only $63 \%$ confidence rate [14]. Companies like Jaguar and Land Rover lose 6\% of their orders due to poor supplier choice and lack of trusted reputation systems that can be used to rank prospective suppliers [15].

This paper tends to answer the question of "How do companies use e-reputation systems and social media networks to select their global trusted suppliers?' In order to address this question, the Reputation-Based model by [16] has been employed. The rationale for choosing this framework can be summarised as follows; Firstly, supplier selection is divided into two phases: supplier discovery phase and supplier selection phase. Secondly, the focus is on evaluating the partners based on trust. Finally, three types of trust, namely goodwill, competence and predictability, are fully addressed. Therefore, by targeting two cases from different industries and countries and by drawing on the mentioned framework, this study tries to provide a better understanding of the role of reputation systems and social media play in the global trusted supplier selection process. Focusing on this issue this research presents a modified ReputationBased model for selecting trusted suppliers.

\section{Global Supply Chain Management: The Challenge}

\subsection{What Is Supply Chain Management?}

In order to survive and sustain growth objectives in the current e-commerce activity environment, organizations have realized that managing their own business is no longer enough [17] [18]; businesses also need to manage their supply chain and therefore need to be involved in managing the network of both upstream and downstream firms as well [17].

As sustainable competitive advantages will be achieved through the extent to which an organization designs its supply chain more efficiently and effectively than its rivals, the efficiency and effectiveness of supply chains has gained the attention of many organizations [19]. The supply chain should be efficient in terms of minimizing the resources used to deliver specific outcomes. It should be effective in terms of designing distribution channels which are acceptable to end-users [20]. Criteria such as delivery performance, product quality, backorders and inventory levels are used as measurement tools for efficiency; whereas service quality and the service needs of focal companies (as well as focal companies' customers) are used as measurement tools for effectiveness [21].

Generally, a supply chain includes multiple companies in order to provide customers with services or products [22]. A supply chain life-cycle is comprised of two main processes: supply chain management and supply chain information [23]. This thesis will consider the supply chain information that focuses on the 
selection of the suppliers for a supply chain. Hence, for the purpose of this research, the term supply chain is defined as follows:

The supply chain includes a set of organizations and activities involved in the flow and transformation of products from the raw materials stage and information flows, through to end user [17]. These tangible and intangible contents flow up and down the supply chain. In this definition the supply chain includes "managing information systems, sourcing and procurement, production scheduling, order processing, inventory management, warehousing, customer service and aftermarket disposition of packaging and materials" ([17], p. 8-9).

As can be seen in Figure 1, internal divisions of the company as well as external suppliers which provide inputs either directly or indirectly can be included in a supplier network. This network also may consist of a set of suppliers of companies' supplier which are called second-tier suppliers [17].

According to the complexity of the supply network, ([21], p. 4) defines three types of supply chain: a "direct supply chain"; an "extended supply chain"; and an "ultimate supply chain". The direct supply chain "includes a company, a supplier and a customer"; the extended one includes "suppliers of the immediate suppliers as well as customers of the immediate customer" and the latter one includes "all the organizations involved in all the upstream and downstream flows" ([21], p. 4). The objectives in the supply chain are to achieve and fulfil all (or some) of the following: "Meet customer demand; Reduce supply chain cost, Improve product margins, Lower inventories; and Increase manufacturing throughput better return on asset" ([21], p. 4).

\subsection{What Is Outsourcing?}

Outsourcing is defined as a situation in which part or parts of the organization's activities are shifted to another organization [9]. The idea of recruiting someone else to carry out specific duties has been around for hundreds of years [24].

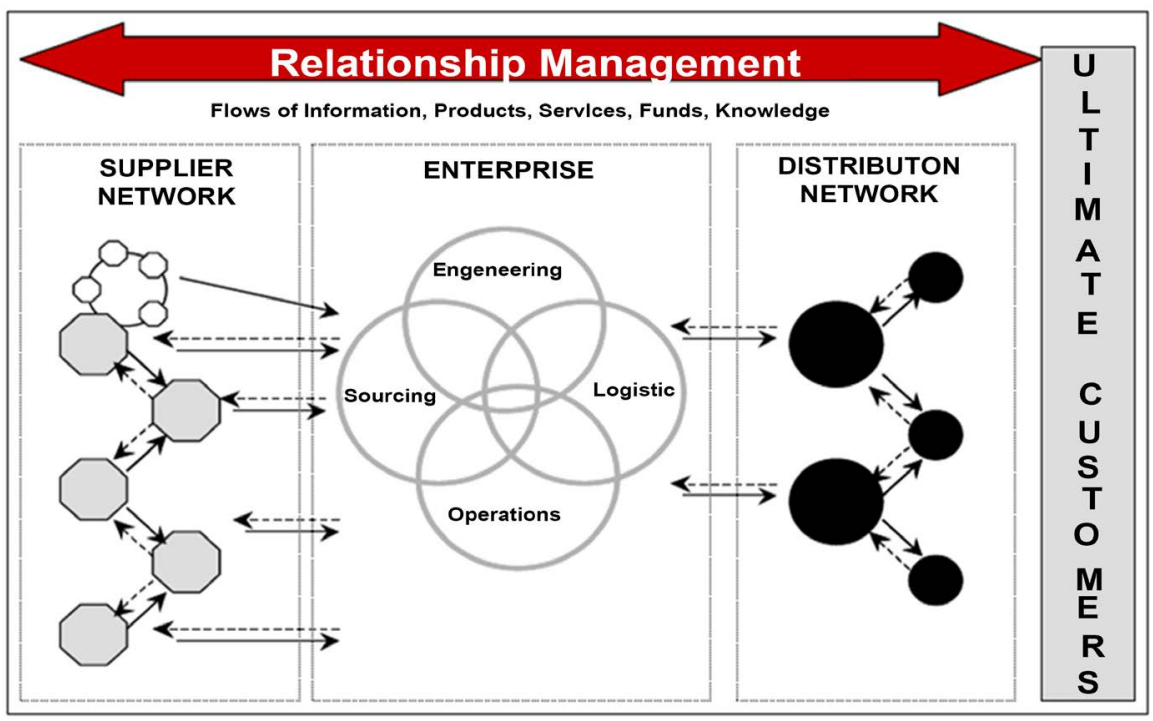

Figure 1. The integrated supply chain ([17], p. 9). 
However, the term outsourcing dates back to the mid-1980s when producing the final products from the raw material themselves was the responsibility of most companies. Labour intensive production tasks and business activities gained the attention of outsourcing. Activities such as the printing press, recruiting the seasonal migrant farm workers and food preparation was outsourced ([24], p. 186).

In the industrial realm, outsourcing began in manufacturing due to the recession. The idea of outsourcing complex production tasks in order to save costs was launched by manufacturers [25]. In order to survive in intense competition, cost saving and downsizing strategies were adopted by manufacturing companies [26]. Most large manufacturing companies could establish their outsourcing relationship with other providers [25]. For example, in the automobile industry, the variety of producers of metal, glasses, electrical products and so on were engaged in outsourcing relationships. Ford Company began to outsource two-thirds of their production processes by the end of 1930s.

Due to cost savings and productivity benefits achieved through global outsourcing, many companies were persuaded to turn over all, or at least some, of their production processes to other providers. Some of the main reasons behind the original trend and the revival of outsourcing are "competition and recession" and "the growth of communication technology" ([27], p. 21).

According to [28] due to the recession, the competition between companies became stronger in 1990s. Cost cuts and downsizing were chosen as mandatory strategies by many companies in order to survive in an environment of intense competition and severe recession [26]. Many companies adopted outsourcing in order to save costs and survive in the competition and recession and it has been found to be the main reason for the outsourcing [28].

The emergence of the Internet both improves the ease of information transfer and reduces the transmission cost [27]. Also, [30] claimed that technological change played a pivotal role in reviving levels of outsourcing; first, the risks of outsourcing reduced as the technological change meant the management, operation and delivery of information services were independent of each other and as a result more opportunities for outsourcing were created. Second, the new possibilities for managing the complexity of issues relating to distance, cost and change management was provided by the combination of technological change and globalization of business. This has created an opportunity for distant vendors offer their products and services.

As a result, outsourcing supply chain activities as a contract manufacturing became the norm in industry. Although, the supply chain outsourcing was focused on the sourcing and procurement of indirect goods and services; gradually organizations have realized the potential of outsourcing for other functions of supply chains such as order management and fulfillment, logistics, master data management and so on [39].

\subsection{Global Supply Chain \& Outsourcing}

Supply chains have been reshaped by the force of globalization and technology 
[1] [2]. Inexpensive telecommunication bandwidth, falling shipping costs, intense competition and customer needs forced companies to operate globally to take advantage of the international product and capital markets [38]. Thus, many product designers, manufacturers and providers are widely distributed in companies with different languages and cultures throughout the world [1] [2].

The benefits of global outsourcing such as delivering products to market more quickly and reducing costs, could convince more and more companies to outsource their supply chain functions. According to a report published by Everest group, a leading research firm, there was a $15 \%$ growth in the procurement outsourcing market in 2012 [40]. The report also indicated that there was a $17 \%$ increase in the total value of contracts including new and renewal from 2010 to reach $\$ 11$ billion in 2011 [31].

Generally, global outsourcing can be divided into two main categories: near-shore and offshore outsourcing [24]. Some literature uses the terms "offshoring" and "outsourcing" interchangeably [32]. The term "offshore outsourcing", however, consists of two terms: "offshore" which is concerned with location (inside the border or outside the border) and "outsourcing" which is concerned with governance (in-house or outsourced) [32].

Offshore outsourcing refers to outsourcing activities in which business processes are performed in lower-wage countries [33]. As offshore outsourcing manufacturing can reduce production costs, it has drawn the attention of many companies [34]. For these companies, offshore outsourcing refers to "the practice of procuring goods or services from outside foreign suppliers, rather than producing them in-house" ([34], p. 539).

Near-shore refers to outsourcing activities "to the low-wage foreign country where is close in distance/or time zone" ([35], p. 16). In comparison with offshore outsourcing, near-shore outsourcing benefits from less "travel cost", "similar time zone", and "close cultural compatibility and communication" [35]. For example, corporations that operate in USA, near-shore their activities in Canada and Mexico [24].

\subsubsection{Benefits of Global Outsourcing}

[33] argued that by adopting the information communication technology and process management infrastructure in the global scope, companies have a chance to select and use the required segments of the supply chain on a variable cost basis. The global outsourcing typically includes activities such as a supply chain redesign, sustainable package review and transportation and inventory optimization which can finally lead to cost reduction [33]. In addition, reduced cost, increased revenues and improved reliability have been cited as benefits of global supply chains by [36].

Accessing new global markets and new channels can be considered as further benefits [33]. Any flaw in providing facilities can be handled by shifting production or redirecting fulfillment to alternative producers to prevent disruption of productivity [33] [37] (Figure 2) has shown that increasing the profitability of 


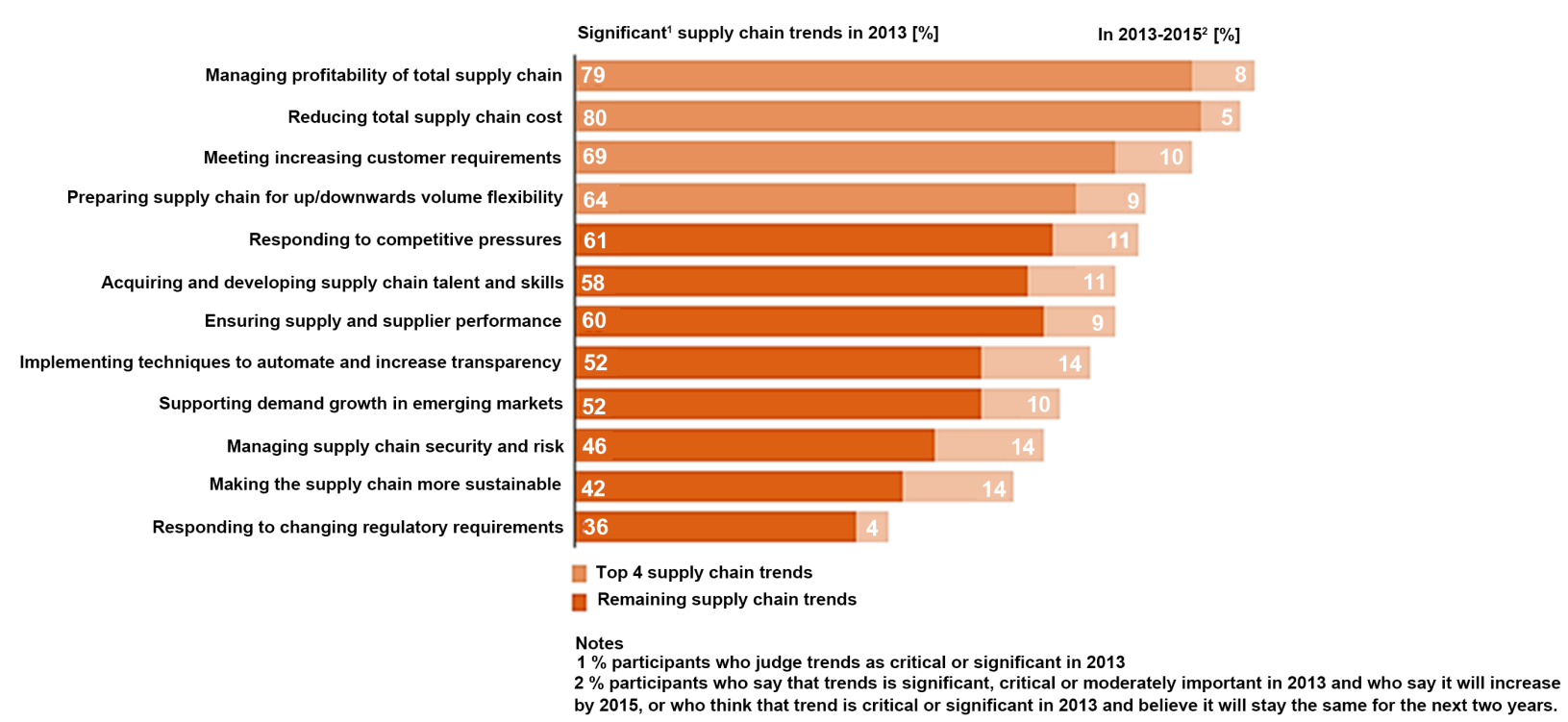

Figure 2. Significant supply chain trend in 2013-2015 ([37], p. 10).

supply chain and reducing total supply chain cost as well as meeting increasing customer requirements are the top priorities of supply chain executives.

\subsubsection{Risks of Global Supply Chain}

Although offshore outsourcing provides significant cost reduction opportunities, global supply chains are more difficult to manage than domestic ones [34]. Because of increased lead time, issues such as transportation costs and inventory cost tradeoffs should be carefully considered and managed given the geographical distances of global supply chains [36]. In addition, concerns of operating globally include different cultures, languages and practices which can have an impact on the business processes such as demand forecasting and material planning ([36], p. 533).

As [41] argues, the advantages of outsourcing opportunities can be influenced by the global economic uncertainties and the growing complexity of many corporate supply chains. Thus the risks, including foreign exchange rate risk, economic and political instability, as well as changes in regulatory environment, influence the advantages of offshore outsourcing [36]. Due to the economic recession, currency exchange rate risk is considered as one of the top concerns for global supply chain [34]. It could obtain the second main highest offshore outsourcing risks amongst global of supply chain executives in 2010 as well [34]. For example, many companies involved in global supply chains were faced with the significant currency change rate risk due to the high volatility of the euro and possible appreciation of the Chinese yuan in 2010 [34]. In addition to the above issues, the special issues in developing countries such as inadequate worker skills, telecommunication infrastructure, supplier quality and availability should be considered in leveraging offshore outsourcing [36]. As ([38], p. 16) asserts: highly coordinated flow of goods, services and information and cash in the global scope are required for global supply chains. 


\subsection{Supplier Selection}

As [42] asserts, without satisfactory vendors it is impossible to achieve the goals of supply chain to produce high quality products at low cost. Thus, vendor selection decisions are an important part of productions and logistics and have drawn the attention of many companies [42]. Although this activity has undergone significant changes during the past decades, the identification and analysis of criteria for the selecting and measuring the performance of vendors has received a great deal of attention from many academicians and practitioners [43].

The work of [44] was the pioneer study of selecting the providers. In this study, he validated 23 criteria for evaluating the provider's performance based on the responses of 300 commercial organizations; as well as primary manufacturing firms. As can be seen in Table 1, Dickson found that quality was considered as an extremely important factor for them. Based on a review of 76 articles between 1966 and 1990 on Dickson's 23 supplier evaluation criteria, [42] concluded that quality, delivery performance and cost were considered as the most important factors.

Table 1. Most important factors by situation [44].

\begin{tabular}{|c|c|c|c|}
\hline Number & Factor & Mean & Relative Importance \\
\hline 1 & Quality & 3.508 & \multirow[t]{4}{*}{ Extreme Importance } \\
\hline 2 & Delivery & 3.417 & \\
\hline 3 & Performance History & 2.998 & \\
\hline 4 & Warranty \& claim policies & 2.849 & \\
\hline 5 & $\begin{array}{l}\text { Production Facilities and } \\
\text { capacity }\end{array}$ & 2.775 & \multirow[t]{11}{*}{$\begin{array}{l}\text { Considerable } \\
\text { importance }\end{array}$} \\
\hline 6 & Price & 2.758 & \\
\hline 7 & Technical Capability & 2.545 & \\
\hline 8 & Financial Position & 2.514 & \\
\hline 9 & Procedural Compliance & 2.488 & \\
\hline 10 & Communication system & 2.426 & \\
\hline 11 & Reputation and position & 2.412 & \\
\hline 12 & Desire for business & 2.256 & \\
\hline 13 & Management and organization & 2.216 & \\
\hline 14 & Operating controls & 2.211 & \\
\hline 15 & Repair service & 2.187 & \\
\hline 16 & Attitude & 2.120 & \multirow{7}{*}{ Average Importance } \\
\hline 17 & Impression & 2.054 & \\
\hline 18 & Packaging Ability & 2.009 & \\
\hline 19 & Labour Relations Record & 2.003 & \\
\hline 20 & Geographical Location & 1.872 & \\
\hline 21 & Amount of Past Business & 1.597 & \\
\hline 22 & Training & 1.537 & \\
\hline 23 & Reciprocal Arrangements & 0.610 & Slight Importance \\
\hline
\end{tabular}


After reviewing the variety of studies regarding supplier selection, [45] divided all the previous works on vendor selection into three categories including conceptual approaches, empirical research, and analytical models. They found that much of the research on the conceptual approach and of the empirical research focused on three important factors for vendor selection: quality, delivery performance and cost. An overview of the important factors for selecting suppliers identified from different studies is provided in Table 2.

\section{Supply Information Systems}

\subsection{Internet-Based Supply Systems}

The Internet has a potential to be considered as a supply chain management tool to "save sourcing time, efficiently locate new suppliers, reduce costs, greatly improve communication with suppliers, help track supplier performance, and free them for higher level, more value-added work" ([56], p. 100).

In addition, the widespread use of e-procurement can empower manufacturing companies to "minimize inventory carrying cost", and can assist by "speeding up cycle times" and "enabling [companies] to produce the products and services to fulfil end users' needs" [56]. Since Internet-based technology has removed physical distances and facilitates the transition to a global economy, more competitive environments for companies have been provided [56]. As the Internet provides a platform for purchasing activities, it can be seen that most companies accept that their suppliers intend to utilize the web for the full range of possibilities of trade processes.

The Internet as push technology provides the opportunity for suppliers to be part of their customers by advertising and providing their services and products directly to them every day [60]. Therefore, the suppliers who fail to invest in e-commerce technology are vulnerable to be replaced by their competitors who have recognized the importance of e-commerce applications [61].

As an Internet service operates throughout the world, it can offer significant opportunities to interact with new unknown suppliers. Although this interaction has substantial profits for the company, it involves risk [62]. In addition to the above mentioned selection provider's factors, trust plays a pivotal role among supply chain participants [16].

Lack of trust can be considered as one of the significant barriers to establishing collaborative partnerships [16]. Trust is affected significantly by partner reputation [63]. The role of reputation in business transaction will be highlighted especially when partners have no previous experience of working with each other [63]. [64] believe that personal experience is more important than the second hand referral of a partner's reputation in building trust. They also mentioned that in the absence of personal experience, trust will be built on the basis of the experiences of others. Before addressing those issues, social media and online community will be discussed. 
Table 2. Summary of some selected studies of supplier selection criteria, revised from ([45], p. 453].

\begin{tabular}{|c|c|}
\hline Author & Supplier Selection criteria \\
\hline Wind et al. (1968) [46] & $\begin{array}{l}\text { Quality/price ratio, Delivery, Technical ability, Information and mar- } \\
\text { ket services, } \\
\text { Reputation, Location, Technical innovativeness, Previous contact with } \\
\text { buyer, Reciprocity, Personal benefits received by the buyer }\end{array}$ \\
\hline $\begin{array}{l}\text { Lehmann \& O’Shaughnessy } \\
\text { (1974) [47] }\end{array}$ & $\begin{array}{l}\text { Delivery, Price, Flexibility, Reputation, Technical specifications, Past } \\
\text { experience, } \\
\text { Sales service, Maintenance, Financing, Ease of use, Reliability, Tech- } \\
\text { nical service, } \\
\text { Preference of users, Confidence in salesmen, convenience in } \\
\text { ordering, Training } \\
\text { Offered, Training required }\end{array}$ \\
\hline Perreault \& Russ (1976) [48] & $\begin{array}{l}\text { Product quality, distribution service, price, supplier management, } \\
\text { Distance to supplier, } \\
\text { Required order size, Minority/small business, reciprocity }\end{array}$ \\
\hline Abratt (1986) [49] & $\begin{array}{l}\text { Technical service, product reliability, after-sales support, } \\
\text { reputation, ease of maintenance, ease of operation, price, } \\
\text { confidence in salesperson, product flexibility }\end{array}$ \\
\hline Billesbach et.al. (1991) [50] & $\begin{array}{l}\text { Delivery, quality, price, response flexibility, technical support, JIT } \\
\text { capability }\end{array}$ \\
\hline Choi \& Hartley (1996) [51] & $\begin{array}{l}\text { Financial conditions, profitability of supplier, financial records dis- } \\
\text { closure, performance awards, conformance awards, conformance } \\
\text { quality, consistent delivery, quality philosophy, prompt response, } \\
\text { long-term relationship, relationship closeness, communication open- } \\
\text { ness, reputation for integrity, product volume changes, short set-up } \\
\text { time, short delivery lead time, conflict resolution, design capability, } \\
\text { after-sales support, sales rep's competence, incremental improvement, } \\
\text { product reliability, low initial price }\end{array}$ \\
\hline $\begin{array}{l}\text { Verma \& Puliman (1998) } \\
\text { [52] }\end{array}$ & $\begin{array}{l}\text { Unit cost of components/raw, materials, quality of } \\
\text { components/raw, delivery lead-time, flexibility in changing } \\
\text { the order }\end{array}$ \\
\hline $\begin{array}{l}\text { Yahya \& Kingsman (1999) } \\
\text { [53] }\end{array}$ & $\begin{array}{l}\text { Delivery, quality, facility, technical capability, management, } \\
\text { financial position, past Performance, attitude, communication } \\
\text { system, responsiveness, desire for business }\end{array}$ \\
\hline Petroni (2000) [54] & $\begin{array}{l}\text { Price, quality, delivery compliance, technological capability, } \\
\text { management capability, production facilities and capacity }\end{array}$ \\
\hline $\begin{array}{l}\text { De Boer \& Van der Wegen } \\
(2003)[55]\end{array}$ & Complexity-fit, cost/benefit \\
\hline Cheraghi et al. (2004) [56] & $\begin{array}{l}\text { Quality, delivery, price, repair service, technical capabilities, } \\
\text { production facilities and capability, financial position, management } \\
\text { and organization, flexibility, reliability, attitude, communication sys- } \\
\text { tem, performance history, geographical location, consistently, long } \\
\text { term relationship, procedural compliance, impression, reciprocal } \\
\text { arrangement, process improvement, product development, Inventory } \\
\text { cost, JIT, quality standards, integrity, research, cultural, reputation } \\
\text { and position in industry, labour relation report, operating control, } \\
\text { packaging ability, training aids, desire for business, amount of past } \\
\text { business, warranties and claims policy }\end{array}$ \\
\hline Bei et al. (2006) [45] & $\begin{array}{l}\text { Price, quality, service, technological capability, management capabili- } \\
\text { ty, reputation }\end{array}$ \\
\hline
\end{tabular}




\section{Continued}

\begin{tabular}{ll}
\hline Shil (2009) [57] & Performance, satisfaction, experience \\
& Quality, delivery, price, manufacturing capability, service, manage- \\
Ho et al. (2010) [58] & $\begin{array}{l}\text { ments, technology, research development, finance, flexibility, reputa- } \\
\text { tion, safety environment, relationship, risk }\end{array}$ \\
& Price, qualitative capabilities, delivery on-time, organization and \\
& management, geographical situation, financial status, capacity and \\
& production capacity, future potential purchases from company, status \\
& in relations industry, individual antecedents, organizational beha- \\
& viour, eagerness to cooperate, policy of warranty and legal claim, \\
Izadikhah (2012) [59] & performance antecedents
\end{tabular}

\subsection{Social Media \& Online Community}

Social media includes the group of online tools, application and sites which by providing dynamic and sharable content, could shift the way people use the web in a more social space [65]. In fact the need to share information and to create content in relationships between groups and communities is demonstrated by the large number of social networks such as Facebook, LinkedIn and Twitter; video sharing such as YouTube; and mass collaboration wikis such as Wikipedia [66].

Several categories of social media have been presented by scholars [67]. Categorising media according to whether social action involved connection, collaboration, cooperation, or communication, [68] presented a framework for social media. Connection refers to networking technologies that give opportunities to make connections between people with content and other people. Collaboration refers to tools that encourage people to collaborate with each other either directly or indirectly on particular issues. Cooperation refers to the use of software in empowering individuals to share information and content with each other in either structured or unstructured ways. Finally, communication refers to platforms that allow people to discuss with each other either by text, image, video or audio artefacts or combination of them [68].

This classification in the business environment can be broken down based on the tendency of business culture to use social media and the complexity of formal organizational structure [68]. As demonstrated in Figure 3, this classification is plotted on a formality/interaction matrix. For example, an organization with formal organizational structures and an individual effort culture prefer to invest in networking technologies to support connections [68].

\subsubsection{Online Community}

An online or virtual community is a group of people who discuss with each other and exchange their ideas through computer bulletin boards and networks [69]. In addition the core attributes of online communities are identified by ([70], p. 29) as follows:

"Members have some shared goal, interest, need, or activity that provides the primary reason for belonging to the community. Members engage in repeated 


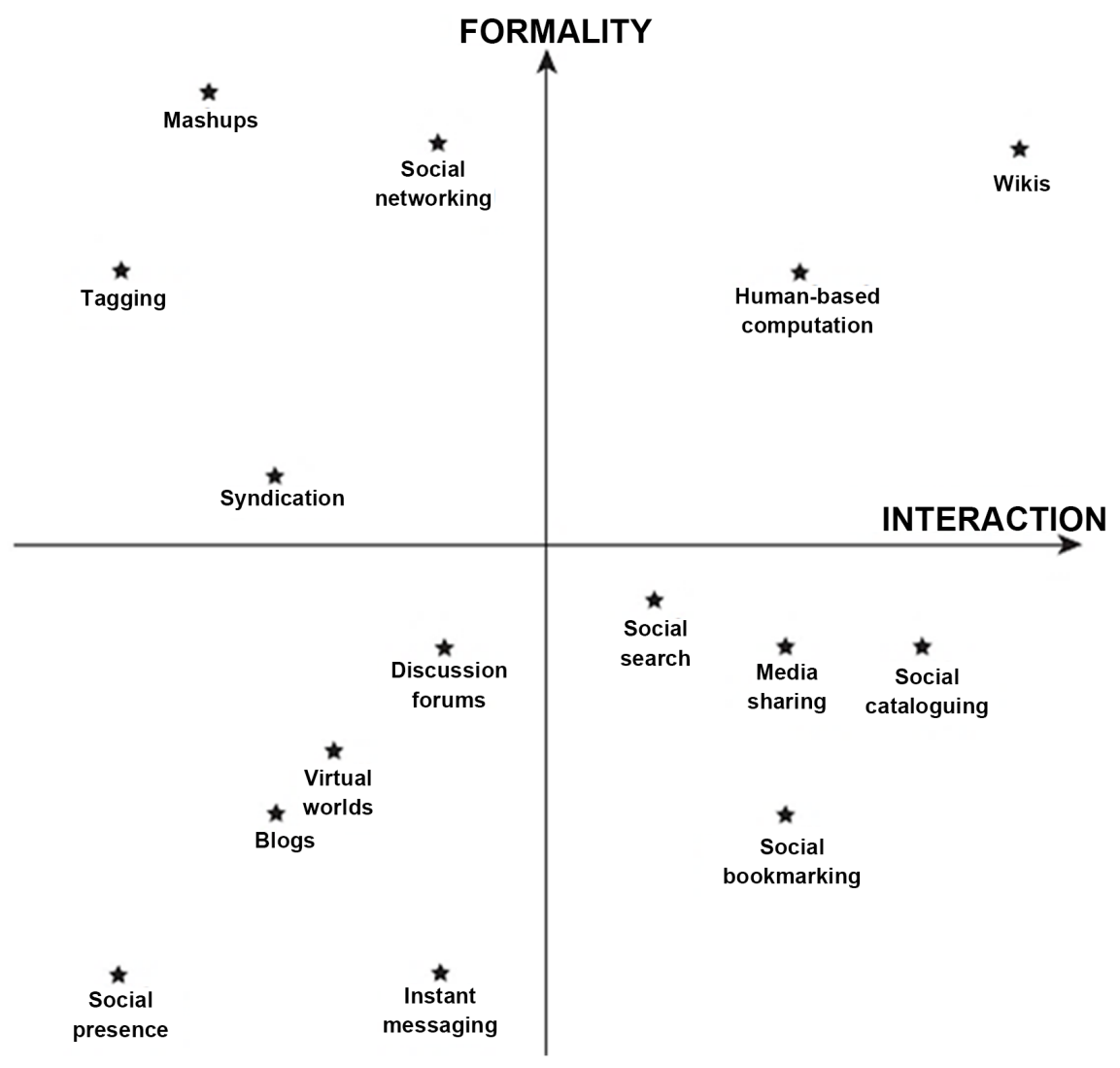

Figure 3. The 4Cs formality/interaction matrix ([68], p. 38].

active participation and there are often intense interactions, strong emotional ties and shared activities occurring between the participants. Members have access to shared resources and there are policies for determining access to those resources.

Reciprocity of information, support and services between members.

Shared context (social conventions, language, protocols)" ([70], p. 29].

[71] asserted that although there are various plausible factors to classify online communities (based on Internet service, the tasks and subjects they relate to, or the role they play in the lives of their members), it is possible to classify it based on social, professional and commercial orientation as shown in Figure 4.

In this classification, a social-oriented virtual community is the original community type from which all other communities have evolved and is subdivided into "relationship building" and "entertainment" types [71]. Professionally-oriented virtual communities are geared toward professionals and discusses from their point of view. Professionals involve communicating and sharing information with other relevant people outside their own group and organization [71]. This virtual community can be subdivided into "expert networks" to develop and document existing knowledge and "learning networks" to acquire knowledge in areas of interest or new subjects. Commercially-oriented virtual communities intend to generate a profit or any financial return. The profit-oriented factors (e.g. whether the community has improved sales directly 


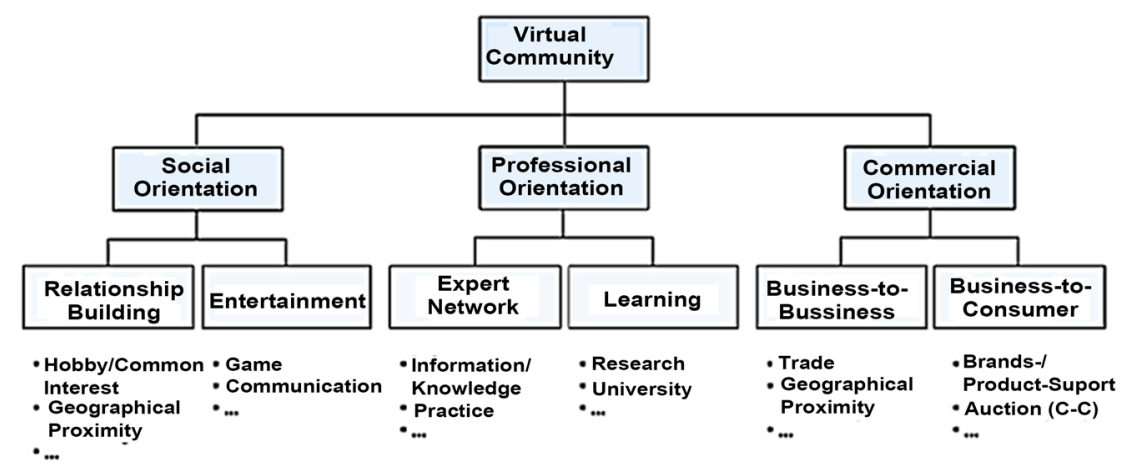

Figure 4. Characterizing the virtual community, adopted from ([71], p. 20].

or indirectly) can be used to measure the success or failure of this type of virtual community [71].

\subsubsection{Trust in Online Community}

Despite the fact that trust is crucial for establishing collaborative partnerships, there is no consensus on the definition of trust between scholars [16]. Trust has been studied in different disciplines: economics, sociology, psychology and politics [72]. It is considered as a measurement of taking a risky choice to maximize gain in economics; whereas in social science, the previous experiences and interaction among individuals is used as a platform to build trust [72]. Random and non-deterministic factors influenced trust and, while it is built very slowly, it can be easily devastated [72]. However, trust is not a simple phenomenon. It "encompasses constructs as diverse as ethic, emotions, morals, values, and natural attitudes" ([73], p. 242). [72] point out that according to the complexity of the definition there are two common definitions of trust: "reliability trust" and "decision trust". The former relates to the reliability of somebody or something and has been described by [74]: "Trust is the subjective probability by which an individual, $\mathrm{A}$, expects that another individual, B, performs a given action on which its welfare depends" ([72], p. 619). The latter relates to adopting risk in building trust and has been described by [75]; "Trust is the extent to which one party is willing to depend on something or somebody in a given situation with a feeling of relative security, even though negative consequences are possible" ([72], p. 620).

In addition, three types of inter-organizational trust in B2B e-commerce have been offered by ([76], p. 545). These are competence, predictability and goodwill trust. Competence trust depends on a partner's skill, technical knowledge and ability to operate the B2B application correctly. The skills of suppliers to produce and deliver high quality products and services on time can achieve a high level of competence trust. Predictability trust depends on the partner's ability to provide the opportunity for other partners to make forecasts and judgements due to past experience. Thus, the chain of positive partner's behaviour can develop a foundation of familiarity which consequently leads to trust. Goodwill trust depends on a partner's "care, concern, honesty and benevolence of other trading part- 
ners" [76:550]. Increased level of cooperation, open communication, information sharing and commitment reinforce the goodwill trust. This trust helps the partners to grasp the benefits such as long term investments and building the reputation of trading partners. Termination of trading partner contracts and bad reputation among partners might occur in the absence of goodwill trust as well [76].

Different parties have access to each other through the Internet without any prior experience or interaction. The relationship between parties in collaborative supply chain as a virtual business relationship might be started by project-based way [16].

The willingness to rely on a third party after the first interaction is defined as "initial trust" by [77]. As trust is considered as long-term relationships, it builds incrementally over time [16]. Although this initial trust might be changed by more interactions and over time, the possibility of future interaction may be determined by them [77]. [77] also point out that initial trust between parties is positively influenced by the perceived reputation. They also asserted that it is possible for new customers to form their opinions regarding the companies' reputation even where they had no previous experience with them. Thus, initial trust is affected by those perceptions [77].

[63] argued that successful supply chain performance has a direct relationship with a high level of trust and strong commitment amongst partners. They asserted that level of trust is significantly influenced by the partner reputation in the supply chain. They also stated that a partner's reputation is essential to trust building, especially where there is a lack of previous experience between partners. On such an occasion the partner reputation is their sole motivation to do business with each other.

\subsubsection{Reputation in Online Community}

Reputation is defined by the Concise Oxford dictionary as "what is generally said or believed about the character or standing of a person or thing" ([63], p. 620). Reputation can be considered as an assessment of individuals or things based on the history of interaction either directly through personal experience or indirectly through recommendation or third party verification [78]. Although the concept of reputation is closely related to trust, there are clear and important differences [72]. Trust decisions can be a transitive process [78]. For example, Alice trusts Bob and Bob trusts Cathy then Alice can trust Cathy as well. The main differences between reputation and trust are that reputation is an objective concept that demonstrates a collective evaluation of individuals or companies whereas trust is a subjective concept that reflects an individual's idea [79]. This difference can be simply illustrated in the plausible sentences: "I trust you because of your good reputation" and "I trust you despite your bad reputation ([72], p. 620). The former sentence explains that based on knowing the trustee's reputation the relying party trusts him. The latter sentence explains that knowing some private knowledge regarding the trustee through either direct expe- 
rience or friendly relationship can impact on his reputation [72]. Therefore, trust is a subjective phenomenon and a judgement that is based on various factors and evidence; while reputation is a collective evaluation of trustworthiness based either on direct experience or the ratings or referral from other members in a community. [72] explained that in trust decision-making, although direct experience usually carries more weight than second-hand and referrals, in the absence of direct experience, decision-making hinges on ratings or referrals from others.

\subsection{E-Reputation Systems}

So far, the notion of trust and reputation has been discussed. Accordingly, a reputation system is based on "allowing parties to rate each other, and to use the aggregation information as rating of a specific party and derive the score in the form of reputation or trust, which can assist other parties in deciding whether to do business with that party in future" ([80], p. 129). In fact, by collecting, distributing and aggregating feedback information about an individual's past behaviour, a reputation system helps individuals make decisions about whom to trust [62]. In this system two fundamental aspects should be considered ([64], p. 2).

1) A propagation mechanism that enables entities to obtain reputation values when required. Two centralized and decentralized mechanisms are available for user reputation propagation. As one can guess from its name, in the centralized approach, the central server is used for storing reputation and whenever there is a need, a query of users regarding the reputation value is sent to a central server. The decentralized approach does not deploy any central server and reputation value of other people is kept and managed by everybody; whenever there is a need, a query of users regarding the reputation value is sent to others.

2) A reputation engine that calculates the value of user reputations based on the various inputs, including feedback from other parties. There is a variety of reputation system: from simple ones which simply added numerical value together, such as e-Bay's reputation system, to advanced mechanisms in which more sophisticated algorithms been deployed, such as Page Rank.

One practical example of a simple and centralized reputation system is employed by e-Bay [81]. In this system the buyer and seller have the chance to rate each other by leaving feedback for each transaction. The reputation system is designed so that buyers can leave sellers negative, neutral or positive feedback and a short comment. Sellers can leave buyers just positive feedback and a short comment. The reputation system is considered +1 point for each positive feedback, zero point for each neutral feedback, and -1 point for each negative feedback. Over time, buyers and sellers develop a feedback profile and, according to the above mentioned score rules, can develop the feedback score as one of the important parts of a feedback profile [81].

Two reasons have been identified for the importance of reputation systems in fostering trust among strangers by [62]. Firstly, past history about the interaction of different parties are used to inform them of their abilities and tendencies. 
Secondly, a motivator for good behaviour can be created by the expectations of reciprocal action and relation in future interaction.

Based on the existence and use of trust and reputation in traditional and online environments, there are two main differences [72]. Firstly, in the traditional environment trust and reputation are based on observation and the physical world. To compensate for the lack of observation and the physical world in an online environment, electronic substitutes are needed. Secondly, as exchanging and collecting information regarding trust and reputation is relatively difficult, it is constrained to local communities in a traditional environment. However, by leveraging Internet-based IT features such as web pages and social media; it is possible to design sophisticated systems for sharing information and communicating on a global scale in an online environment. Changes to the way reputations are built, shared, and modified change the way individuals interact online and the way markets operate [82].

The greater the interest online: the greater the importance of online reputation systems. As shown in Table 3, reputation systems are used for things such as programmers, lawyers, high school teachers, charities and resort hotel operators. Reputation systems can be used to enhance customer support, establish trust and consequently increase the number and quality of transactions [82]. A study by [62] on eBay reputation has shown that high ranked reputation sellers could achieve 8 percent more transactions than sellers with no reputation. The aim behind eBay's reputation system is defined as follows:

"Leaving honest comments gives members a good idea of what to expect when dealing with other members. Leaving Feedback is also a way to express your appreciation for a job well done. Finally, if you are a buyer, you can help spread the word about a seller you like, and if you are a seller, you can help recognize and reward loyal customers, which encourages them to buy from you again" [81].

\subsubsection{Types of Reputation System}

Despite the fact that reputation systems can increase the value of trust and cooperation in transactions, the inevitable errors in reputation systems will have unfortunate consequences for businesses [82]. For example, the good sellers will pay a heavy price if they are cin the e-bay reputation system. Sometimes these errors result from the intentional endeavour of competitors to ruin each other's reputations [82]. However, other errors result from the fact that different people behave differently in different situations. This kind of error is less concrete because "a reputation is only what some people might think not a hard truth" ([82], p. 7). Further, as people in the current reputation system rely on anonymous people and unknown information resources, they may be hesitant as to the reliability of reputation system as well. Therefore, leveraging the social interaction is considered as one way of increasing the reliability of reputation system [83].

[83] mentioned that in reality, business partners and friends have greater 
Table 3. How they stack up: Some other ratings and reputation sites ([82], p. 31).

\begin{tabular}{|c|c|c|c|}
\hline NAME & WHAT IT IS & COMMENTS & OUR RATING \\
\hline $\begin{array}{l}\text { BizRate } \\
\text { http://www.bizrate.com/ }\end{array}$ & Customers rate business & $\begin{array}{l}\text { See the tension between the urges to sell } \\
\text { and telling the truth }\end{array}$ & $* * *$ \\
\hline $\begin{array}{l}\text { ChoiceTrust } \\
\text { http://www.choicetrust.com/ }\end{array}$ & $\begin{array}{l}\text { Background checks on doctors, } \\
\text { nannies, contactors }\end{array}$ & Filtering out lemons & $* * *$ \\
\hline $\begin{array}{l}\text { CitySearch } \\
\text { http://www.citysearch.com/ }\end{array}$ & $\begin{array}{l}\text { Reviews of restaurants, bars, shops, } \\
\text { clubs, etc }\end{array}$ & What's good in the hood & $* * * * *$ \\
\hline $\begin{array}{l}\text { Hot or Not } \\
\text { http://www.hotornot.com/ }\end{array}$ & $\begin{array}{l}\text { Are you a hottie, or do you just think } \\
\text { you are? }\end{array}$ & $\begin{array}{l}\text { Get the superficial part of dating over } \\
\text { with quickly }\end{array}$ & $* * * *$ \\
\hline $\begin{array}{l}\text { Landlord Protection Agency } \\
\text { http://www.thelpa.com/lpa/ntrb_description }\end{array}$ & $\begin{array}{l}\text { Landlords rate tenants; other sites let } \\
\text { tenants rate the landlords }\end{array}$ & $\begin{array}{l}\text { Non-slumlords check to see if you'e a } \\
\text { slummer }\end{array}$ & ** \\
\hline $\begin{array}{l}\text { Sarlo's Guru Rating Service } \\
\text { http://www.globalserve.net/-sarlo/Ratings.htm }\end{array}$ & $\begin{array}{l}\text { Which of } 1250 \text { religious guru is right } \\
\text { for you? }\end{array}$ & $\begin{array}{l}\text { Not much feedback from the } \\
\text { enlightened ones, unfortunately }\end{array}$ & $* * * *$ \\
\hline $\begin{array}{l}\text { The Erotic Review } \\
\text { http://www.theeroticreview.com/ }\end{array}$ & Customers rate sex workers & Not safe for work & $* * *$ \\
\hline $\begin{array}{l}\text { Zagat Survey } \\
\text { http://www.zagat.com/ }\end{array}$ & $\begin{array}{l}\text { Ratings for tens of thousands } \\
\text { restaurants around the world }\end{array}$ & Zagat-rated mean " +1 " by default & $* * *$ \\
\hline
\end{tabular}

influence than strangers on making the decision to buy products. Thus, greater accuracy and trustworthiness of submitted information on reputation system can be achieved by the integration of social networks with a reputation system. Nevertheless, in order to reduce the rate of errors in reputation systems, different operative mechanisms have been introduced and employed. Several different reputation systems based on differences in ways of computing reputation have been listed in below Table 4.

\section{Conceptual Model for E-Reputation Systems}

There are highly cited models that map supplier selection process, including [85] and [86] and [16]. While [85] focus on the green environment and selecting partners in the recycling industry, they ignore explaining the routine process followed in standard production lines. [86] overcomes this problem by offering a decision making approach that purchasing and logistics teams follow in a day-to-day fashion. However, both fail to give a comprehensive view of how online and social media supplier selection follow different routines and processes. Accordingly, our "Reputation-Based model for selecting trusted partners", was developed based on [16]. This model consists of two main phases: discovery and selection. In the discovery phase the potential suppliers that were willing and proved to be capable of collaborating are identified and added to a candidate list. In the selection phase the most reputable suppliers are selected based on referral and reputation systems. In this model referral network is also utilized to verify candidates from others who had previously collaborated with suppliers. As shown in Figure 5, all information is then aggregated to develop a trust score based on competence, good will and predictability trust.

In this model, referral systems rely on available resources in the distributed environment called a referral network. The idea behind this is that the verifying request is sent to trusted partners and if they had an experience with suppliers, a 
Table 4. Different reputation systems ([84], pp. 15-23).

\begin{tabular}{|c|c|}
\hline Name & Definition \\
\hline $\begin{array}{l}\text { Accumulative } \\
\text { systems }\end{array}$ & Calculate the reputation of an agent as the sum of all given ratings. e. g. e-bay \\
\hline Average systems & $\begin{array}{l}\text { The reputation of an agent is computed as the average of all ratings that the } \\
\text { agent has received. e.g. Jurca and Faltings system; Yu and Singh system }\end{array}$ \\
\hline Blurred Systems & $\begin{array}{l}\text { Provide a reputation metric with an unspecified time-dependent weight } \\
\text { function, where old ratings lose their influences on the current reputation over } \\
\text { time. An agent behaves like it did the last time. e.g. Only last system }\end{array}$ \\
\hline Beta System & $\begin{array}{l}\text { It is designed with the purpose of predicting statistically an agent's behaviour in } \\
\text { its next transaction. By evaluating the reputation values concerning previous } \\
\text { transactions, the reputation system derives the probability that an agent will } \\
\text { behave good or bad in the next transaction. }\end{array}$ \\
\hline Adaptive Systems & $\begin{array}{l}\text { It is a reputation system based on the following principles: } \\
\text { - The reputation value of a user is never lower than the reputation of a new } \\
\text { user. } \\
\text { - Users with very high reputation values experience smaller rating changes } \\
\text { than users with a low reputation. } \\
\text { - When two users interact more than once, only the most recent rating among } \\
\text { them is considered. }\end{array}$ \\
\hline ReGreT System & $\begin{array}{l}\text { It is a reputation system in which agents themselves evaluate reputation in a } \\
\text { decentralized way. In ReGreT, each agent has the capability to evaluate the } \\
\text { reputation of other agents. }\end{array}$ \\
\hline Perseus System & $\begin{array}{l}\text { It is a personalized reputation system that aims to overcome the problems ex- } \\
\text { isting in most centralized systems for online marketplaces. }\end{array}$ \\
\hline
\end{tabular}

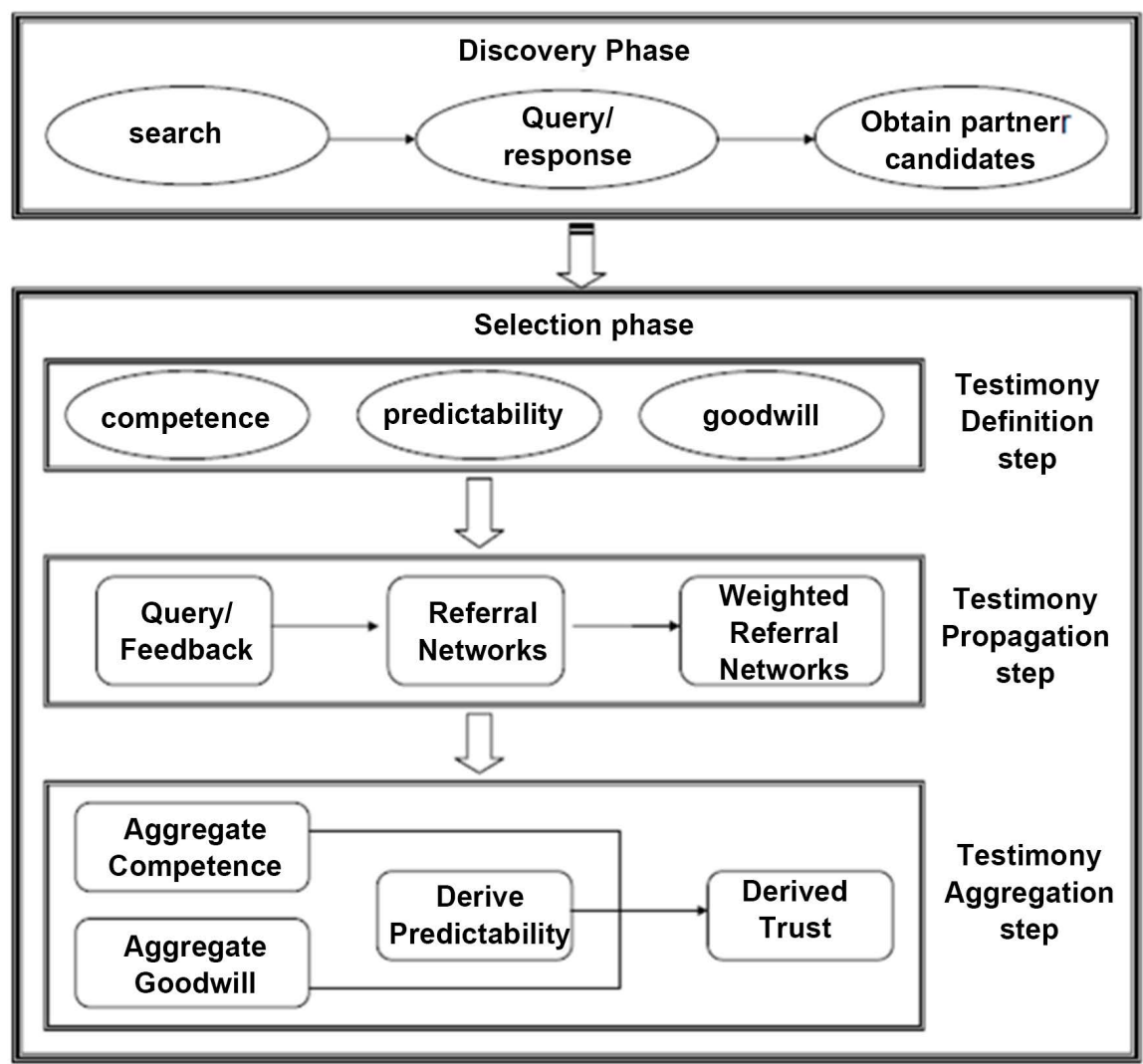

Figure 5.The trusted partner selection ([80], p. 130). 
response is given. Otherwise, the trusted partners ask for verification from other acquaintances. Finally, the answer is given if partners are confident in the ability of the suppliers. In fact, a referral is given if "the referring party has sufficient confidence in the relevance of the party being referred" ([76], p. 130). As can be seen in Figure 5, the selection phase consists of three steps: testimony definition, testimony propagation, and testimony aggregation. The testimony definition step utilizes the three types of inter-organizational trust proposed by [76] (goodwill, competence and predictability) to define information elements. In the testimony propagation step, partner verification is sought through other neighbours or through referral networks. Finally in the testimony aggregation step, the required information regarding the survey of company is gathered and based on that information; the trust scores for competence, goodwill and predictability are calculated. The supplier with the highest score will be selected.

\section{Research Methodology}

The researchers followed a judgmental sample method to choose SCM and purchasing professionals in two cases [87]. In this method the most suitable cases to answer research questions were selected by the researcher [88]. Since the research aims to understand the role of e-reputation systems and social media in selecting suppliers, two companies which already have global supply chains were chosen.

The first case is Rare Pink, a company which works in the diamond industry in the UK. This case was selected as the highest user of e-reputation system to perform their global supply chain in South Africa, India, UAE, and UK. Participants have been approaches based on their level of involvement in the supplier selection and evaluation process (e.g. Supply chain managers, senior procurement specialists, purchasing coordinators, and purchasing assistants). All eight professionals involved in the process have been interviewed.

The second case is $I D A C O$, a company which works in the automotive field in Egypt. This case was chosen based on their heavy use of e-reputation systems as reported by the ministry of investment in Egypt. However, a snowball sampling technique has been followed due to lack of clear list of staff involved in the supplier selection and evaluation process. Twelve interviews have been interviewed, including Supply chain managers, senior procurement specialists, purchasing coordinators, and purchasing assistants.

The interview guides (questions) were drawn from our conceptual model discussed above. The length of the interviews varied between 20 minutes to $45 \mathrm{mi}$ nutes. In the Rare Pink case all interviews were conducted in English. In the IDACO case all interviews were conducted in Arabic to avoid any misunderstanding.

Secondary data was also collected through relevant up-to date articles from journals in this field and corporate archives reported during the last five years when they started to use e-reputation systems. According to ([89], p. 315) secondary data "has already been collected and recorded by someone else". This 
study relied largely on academic a wide set of information systems and supply chain journals to support the analysis of the empirical data.

Data analysis followed three phases of summarising, grouping and structuring of meaning process [88]. To structure and analyse data, the interviews transcripts are thematically written and maintained in English language. The template analysis has been employed to codify data and to trace quotes mentioned by interviewees. Initial codes were invited/deduced from the conceptual framework, but further tree codes were added to explain issues of selection, evaluation, trust, reputation, and system use. The final template allowed the researchers to compare and contrast the strategies followed for supplier discovery and selection phases in both companies. The process of grouping findings was accompanied by reading and rereading the summaries and transcripts. Finally, the structured data were analysed through comparing the two cases with my framework.

\section{Research Findings}

This section addresses the empirical data from selected companies. To begin with, the background of the case will be presented and it will be followed by describing the process of suppliers searching and selecting for each case. The findings of this section were used as a basis for the analysis of research questions in the next section.

\subsection{Case 1: Rare Pink}

Rare pink is an online retailer of diamond jewellery, engagement rings and diamonds in the UK. It was established in 2009. The office of the company is located in Manchester and it has 10 employees who are responsible for finding suppliers to buy the product and getting orders in or for fulfilling orders which come in from customers. Diamond Africa is a sister company for Rare Pink and $60 \%$ of its stock belongs to Diamond Africa. In fact, they could run a portal website whereby each order placed on the Rare Pink website in the UK will be visible and traceable with Diamond Africa employees in Africa. Rare Pink is predominantly working with five suppliers from South Africa, Israel and India. The company buys loose diamonds from these suppliers and, depending on customer orders, assembles them into engagement rings and other types of jewellery. The company provides a brochure in which each product has been shown by the unique product number. Customers have an option to order the products with a specification mentioned in the brochure which is called standard order or change the specification of products in terms of size, colour or shape of products and so place an order based on their needs, which is called an unusual order. As an online company, all the processes of receiving an order and packing the products should be conducted within 72 hours.

\subsubsection{Searching for a Supplier}

The company has a good relationship with five suppliers-three suppliers from South Africa and two suppliers from Israel and India. The reason behind select- 
ing those suppliers is that they are a producer and have their own mines.

"By selecting those suppliers in practice we have eliminated intermediaries. So we can obtain the loose diamonds from producers directly." (Senior procurement specialist)

In collaboration with those suppliers, the company gets more flexibility to offer diamonds in different shapes, colours and sizes. The company also could provide customers with a brochure including the various products at reasonable prices.

“...We try to offer various products in our brochure. Customers can easily change the products in a brochure in terms of diamond shape, colour or size. Our products are provided at least $40 \%$ off the retail price." (Purchasing coordinator)

As the price for standard orders are identified, the customers were asked to pay online with their order. After receiving the payment, the company will provide customers with a receipt and order number as well as a diamond certificate. The standard orders will be dispatched within 24 hours and the customers can trace the process of their order whenever they want with their order number.

"...As the standing order has already been determined, after payment process, we will send an order to specific supplier and within 24 hours the products will be dispatched to customer delivery address." (Senior procurement specialist)

In terms of unusual orders, the company will search through two trusted reputation websites to consider potential suppliers and create the candidates list.

“...We rely on two websites namely domain tools and IDEX online to find potential suppliers for unusual orders. By becoming a member of those websites, we could use them. So we pay a monthly subscription fee of 100 pounds for each of them". (Senior procurement specialist)

“...Our five main suppliers also have a high ranking in those websites." (Purchasing coordinator)

After finding the potential suppliers including main five suppliers, the company will contact them (in English) either by email or phone. After getting their confirmation, the request for a quotation will be sent to them. The price and condition of delivery will be received through an official e-mail. It should be noticed that as an unusual order the price is not given, the company will be in touch with customers and within a maximum of 72 hours customers will be informed of prices and other conditions.

\subsubsection{Selecting a Supplier}

As mentioned above, for standard orders the suppliers already have been selected. For unusual orders, the company will select an appropriate supplier among the candidates list. However, the five main suppliers have precedence over all other suppliers.

"...We prefer to choose our main five suppliers if they could provide an unusual order with reasonable price.”

(Senior procurement specialist) 
Criteria such as the price, quality, and delivery time, type of delivery, return conditions and previous history are crucial to choose an appropriate supplier.

"...As we are the small retailer company we cannot afford the shipping process." (Senior procurement specialist)

"... We only consider those suppliers that accept the FOB model." (Purchasing coordinator)

It is important that the suppliers were ranked on both two websites. The company also prefers to work with producers rather than intermediaries to get more flexibility. As it is an online company, the speed of packing and dispatching processes is also a very important factor for selecting suppliers. Finally, there is a customer feedback on a website that should be fulfilled by customers regarding their products and the service they have received. This feedback will be used as a history of a supplier's performance. The company considers these histories when reselecting suppliers.

“...We never reselect the suppliers with poor customer satisfaction feedbacks for unusual orders even if it was one of our main five suppliers." (Senior procurement specialist)

Finally according to those criteria the suppliers were ranked and the most suitable supplier for the specific order will be chosen.

\subsection{Case 2: IDACO}

IDACO is the pioneer holding factory in the wiring harness in Egypt. This company has run the wiring harness business since 1986 with two factories in the industrial zone in the 6th October City. It has more than 1500 employees. Also, more than $60 \%$ of the local market share belongs to this company. Its local customers include TEMSA Egypt, Nissan Motors Egypt, Toyota Motor Engineering Egypt, LADA, Hyundai, GM, CHRYSLER, Mitsubishi, JAC, Great Wall, Mahindra and ZAHAV Egypt. This company also exported its product since 2005 to the UK, Fiat Italy and Volkswagen Germany. In order to support its product, this company has global suppliers. Establishing an Enterprise Resource Planning (ERP) system helps this company to manage its procurement process as well. The foreign procurement division of this company is in cooperation with the operations, accounting, ERP and material resources planning divisions. In fact, the operation manager orders material by asking request for specification and sending to the ERP \& MRP manager. Then, the ERP \& MRP manager asked request for a quotation from the foreign procurement division. The foreign procurement specialist contacts overseas suppliers and the purchasing process is started.

\subsubsection{Searching for a Supplier}

The procurement strategy of IDACO is based on 11 global supplier partners, which typically have a captive relationship with sort of alliance, for providing core components. Any request quotation that is related to these partners is directly sent to them. 
“...We are exclusive agent for 11 global suppliers in Egypt. We have strong economic and political relationships with these suppliers... These suppliers provide the core components of company." (Purchasing manager)

"...Any material request related to these partners directly will purchase from them."

(Purchasing specialist)

After receiving the request for quotation, the list of potential suppliers according to universal material code, are provided by surfing particular web sites and governmental websites such as the American Chamber of Commerce and governmental Ministry of Trade and Investment website.

“...Each material have a unique universal code, accordingly we will rely on four major websites to find potential suppliers. free particular social media website such as Alibaba, global governmental website, our trade and investment ministry website and finally the supplier website. "(Purchasing manager)

"...I always check the website of potential suppliers and I search for their certification and their internal ratings in their industry." (Purchasing specialist)

In addition, the suppliers which are introduced by friends and other company should provide the registration certificate and ranking assigned by their own trade organization.

"...To consider any potential supplier, the credibility of the supplier is very important for us." (Purchasing manager)

The candidate suppliers are mostly considered from China, Germany, UK and Singapore.

"...For a huge amount of low price materials such as wire we mostly rely on Chinese companies, however, for materials which need high quality such as an engine, we mostly rely on British, German or Singaporean companies". (Purchasing specialist)

All credible suppliers throughout the world, except Israeli companies, have a potential to be considered as candidate suppliers.

“...We are not allowed to work with Israeli companies". (Purchasing manager)

After providing the list of potential suppliers, the purchasing specialist contacts the suppliers via e-mail or phone and asks for price and delivery preferences. It should be noted that in this company, the purchasing specialists have passed the engineering training and depending on the case, they have an ability to speak and write in Mandarin, Italian, English and Spanish.

“...We asked them to provide us with information regarding price and type of delivery free on board (FOB) or cost insurance freight (CIF)...In terms of CIF the shipping cost and insurance issue must be considered as well'. (Purchasing manager)

"...Due to the time zone differences between suppliers and our company, we have been provided with an official mobile phone for calling suppliers at any time. All conversation must be recorded and reported to our manager as well." (Purchasing specialist) 
After getting confirmation of information regarding price list and type of delivery through an official e-mail, the potential suppliers are considered in the candidates list.

\subsubsection{Selecting a Supplier}

For each requested quotation, the purchasing division relies on the candidates list. If the requested materials have already been purchased and there is the consent of relevant supplier performance, the price request will be sent to the supplier. Criteria such as the previous history, previous price, on time delivery and delivery rules are crucial to existing suppliers in the re-selection process.

"...After receiving the code of materials from ERP manager and we will check them in system to find the material purchase history. If we have been ordered these materials before and we were happy with the performance of existing suppliers we will send the request for price for purchasing the materials again." (Purchasing specialist)

If the company is not satisfied with the previous performance of suppliers they will not send them any more requests for pricing.

"...Issues such as quality, on time delivery, and stick to delivery rules were important to reselect suppliers. For example, receipts of goods need to be matched with the invoices for customs clearance. Otherwise, we will not have any access to our ordered materials and will lead to delays in delivery." (Purchasing manager)

The company checks the supplier's price. If a supplier provides them with a reasonable price, the company finalise the order, otherwise the company will search for selecting another supplier from the candidates list.

"...Every month we update our price list automatically, so if the price offered by the supplier was unreasonable we will search for another supplier." (Purchasing manager)

In case of selecting new suppliers, type of delivery is also considered as an important factor.

"...Although we accept both delivery types for considering candidate suppliers, we prefer suppliers which can provide us with FOB delivery.” (Purchasing manager)

Also, the ability to support company on a Saturday and Sunday is considered as an important issue.

“...As you know we are closed on Friday while most of our suppliers are closed on Saturday and Sunday. In fact, we will lose three days. So it is important for us that our suppliers are able support us on Saturday and Sunday." (Purchasing specialist)

The company also was suspicious about the performance of suppliers: especially from China.

"...We should evaluate our suppliers continuously. Sometimes they sent us fake product numbers. It happens mostly with products which consist of two parts. They considered the product number just for the first part. And then we 
should order separately the second part as a new product number." (Purchasing specialist)

Finally according to those criteria the suppliers were ranked and the most suitable supplier for the specific request for quotation will be chosen.

\section{Research Discussion}

Based on Chen \& Lin's model for reputation systems [16], this section contrasts the empirical findings with the literature findings. Then a revised model is proposed to better inform the role of e-reputation systems in the global trusted supplier's selection and to match the "bedside" history of the selected cases. Since in this framework the selection of suppliers has been divided into two phases of supplier discovery phase and supplier selection phase, it is possible to elucidate the role of reputation systems in both phases. In this framework, by breaking down trust into three-goodwill, competence and predictability trust-a better opportunity to understand the role of trust in selecting global trusted suppliers is provided. By comparing the empirical findings with this framework and other theoretical findings, it is possible to find out the comprehensive response to the research question. Thus, this section clarifies how the research question is answered and how the revised model is built.

"How do companies use reputation systems and social networks to select their global trusted suppliers?"

To answer this question, based on the framework the role of reputation system and social networks have been examined in two phases of the supplier discovery phase and the supplier selection phase.

\subsection{Supplier Discovery Phase}

Both selected companies had established suppliers. Rare Pink had a good relationship with five important suppliers in the field of diamonds and through the collaboration with them it could develop a brochure. IDACO on the other hand had 11 alliances with partner suppliers. Consistent with [72] argument that in the absence of direct experience with new suppliers, the findings have shown that both companies relied on reputation systems to create their candidates list. However, to achieve this list they have employed reputation systems in different ways.

For searching suppliers, Rare Pink relied on two web reputation systems in which the diamond suppliers have been ranked. As the company sought to find suppliers that could provide them with diamond certificates, they focused on diamond producers who have their own mines. The diamond producers have been listed in those web reputation systems. Accessing the information regarding the supplier's website, email address and phone numbers as well as clarity of purchasing terms and conditions in those websites could lead to the good will trust building. The company could obtain the necessary and trustworthy information about its orders through the reputation systems. In fact, when a supplier 
is listed in those reputation systems it means that the others were satisfied with that supplier's behaviour and performance.

Thus, it could give an assurance regarding the honesty of the suppliers and consequently goodwill trust was increased. In addition to reputation systems Rare Pink also communicated with suppliers through email and contact numbers to resolve any doubt about the aspects of its orders. In those websites the suppliers had also been ranked based on their performance and their ability to provide high quality licensed products. The main criterion for Rare Pink was a type of delivery. As this company was an online company with few employees, it did not have enough capability to handle shipping product processes. Thus, it could cooperate with suppliers which could offer the FOB model of delivery and could send the products directly to the customer.

The information regarding the type of delivery was provided clearly on those reputation websites. Thus, they could provide the company with the initial competence trust. Furthermore, considering suppliers which are ranked in both websites also provided the company with sufficient competence and predictability trust. This finding is in consonance with the argument of [77] that the initial trust between parties is positively influenced by the perceived reputation. It can be concluded that in this case, after obtaining the adequate goodwill, competence and predictability trust, suppliers were added to the candidate list.

For searching suppliers in IDACO case, it can be seen that in the absence of direct experience, the company relied on three different websites including reputation websites, international governmental websites and governmental Ministry of Trade and Investment. As the request for quotation of the company included a large number of materials, the credibility and reputation of candidates were very important. This information has been obtained through the use of those websites.

For IDACO, credibility of suppliers was very important. When the suppliers were listed in the governmental Ministry of Trade website and international governmental website, it means they had a sufficient capability and the ability to address their customers order. The rank and presence of suppliers on all those websites could build both good will and competence trust. In this case, it can be observed that a greater degree of accuracy and trustworthiness of information about suppliers can be achieved through the integration of social networks with the reputation system [83].

The social media such as Linkedln could provide the company with other customer feedback. So, the more customers who knew the suppliers: the higher the level of trust. In addition, in this case the more positive feedback could increase the level of trust as well. Consequently, the sufficient goodwill and competence trust has been obtained by integrating the information regarding those three websites with social media. The suppliers which were cited and ranked in more websites could provide a greater level of competence, goodwill and predictability trust. In this case, as with the Rare Pink Company, adequate goodwill, competence and predictability trust play a pivotal role to consider the suppliers 
in the candidates list.

In comparison with the framework posed, the empirical findings have shown that in the supplier discovery phase both companies-in the absence of direct experience-rely on web reputation systems to select their candidate suppliers. In addition, as the number of suppliers and type of materials of IDACO were different from Rare Pink, the company considered social media as complementary tools for verifying the suppliers. Goodwill trust and competence trust have been seen as a crucial issue to select candidate suppliers in this phase. Furthermore, consistent with [76] the findings have shown that in the absence of direct experience, both companies relied on reputation systems as the main tools to build a goodwill, competence and predictability trust. The clarity and accuracy of purchasing conditions mentioned in the web reputation systems could reinforce those types of trust. In addition it could be concluded that under specific circumstances where web reputation systems seem to be inadequate to provide companies with satisfactory trust, social media might be used as a complementary tool to provide more detailed information regarding the suppliers. This issue also is in agreement with Ehsaei [83].

\subsubsection{Supplier Selection Phase}

Both companies have their own reputation systems to reselect their current suppliers. Rare Pink provided a facility to collect customer feedback regarding each purchase. This feedback is considered as a basis to evaluate the suppliers. The importance of the good feedback also has been highlighted in the behaviour of Rare Pink with its five main suppliers in unusual order circumstances. The findings have shown that if they cannot satisfy its customers, Rare Pink may delete its five main suppliers from the candidates list of the unusual orders.

Based on the criteria such as, quality, and type of delivery the suppliers obtain the level of goodwill and competence trust. For the first time, the supplier with the highest level of trust would be selected as a trusted supplier for a specific order. The findings have indicated that past history has a significant role in the supplier's re-selection process. In fact, dishonesty, low quality of products and non-compliance with contract, delay on delivery time and reneging on the contract can lead to the bad reputation of suppliers. Recalling from [72] trust is built very slowly but it can be easily devastated. It can be concluded that receiving bad feedback regarding the supplier's performance leads to the destruction of goodwill and competence trust. So, it can be argued that the first mistake of the suppliers in the competitive environment can be their last mistake. This issue is in consonance with the argument that level of trust is significantly influenced by the partner reputation in the supply chain [63].

In agreement with [72] about the preferences of direct experience to second-hand and referrals in any trust building, the findings have shown that both companies also rely on their own reputation system to judge their suppliers and bad reputation of their current suppliers in other reputation websites is not considered any more. 
The reputation system of IDACO is totally different from the Rare Pink one. As the company employs an ERP system, the reputation system was based on the company's ERP system. All the activities of suppliers ranging from price to type of delivery were registered in the system. Thus, past history of suppliers plays a pivotal role in suppliers' reselection decisions. In this company any dissatisfaction with the performance of suppliers means the current supplier will have little chance of re-selection. For example, when the current provider increased the price sharply without any reason, it destroys its goodwill trust. As a result, the supplier has reduced the chances of reselection and the findings have shown that in this circumstance the company will search to find a new supplier from the candidates list.

In addition, recalling from the argument that the chain of positive partners' behaviour can develop a foundation of familiarity which consequently leads to trust [76]. The findings have indicated that the better the reputation, the higher the predictability trust will be. In the case of IDACO, it was observed that as Italian, British and Singaporean suppliers always acted professionally, the company preferred them to Chinese companies. Thus, in the supplier selection phase presence of reputation system regardless of whether it is based on customers' votes or assessment by the company could reinforce goodwill and competence trust as well as predictability trust. In comparison with the framework, the findings have indicated that in this phase both companies relied on their own internal reputation system rather than referral networks. In this phase, fulfilling the crucial criteria could increase the goodwill and competence trust. Thus, higher levels of goodwill and competence trust increased the chance of being selected as a supplier for the first time. The past history or reputation of suppliers was a key factor in decisions to reselect the current suppliers. The findings have shown that in both companies the internal reputation system could provide a company with the necessary information regarding the performance of suppliers. A good reputation could increase the level of goodwill, competence and predictability trust which consequently could increase the chance of re-selection. The revised framework based on this research finding has been depicted in Figure 6.

As can be seen in the supplier delivery phase, companies search the suppliers through reputation systems and/or social media. In this phase reputation systems can provide the companies with adequate information regarding the capabilities and competencies of suppliers. Being in many reputation systems with high rankings would mean that the supplier could attract the attention of other customers and would be able, in both behaviour and performance, to satisfy them. Thus, the initial goodwill, competence and predictability trust are provided by leveraging reputation and/or social networks. In this phase the crucial criteria such as (political issue and type of delivery) to select the suppliers are also imposed to find the appropriate trusted candidate. For example, in my cases, IDACO was not able to choose suppliers from Israel or Rare Pink was not able to deal with the shipping process. Thus, the appropriate candidate with the sufficient trust will be selected from the candidate list. 


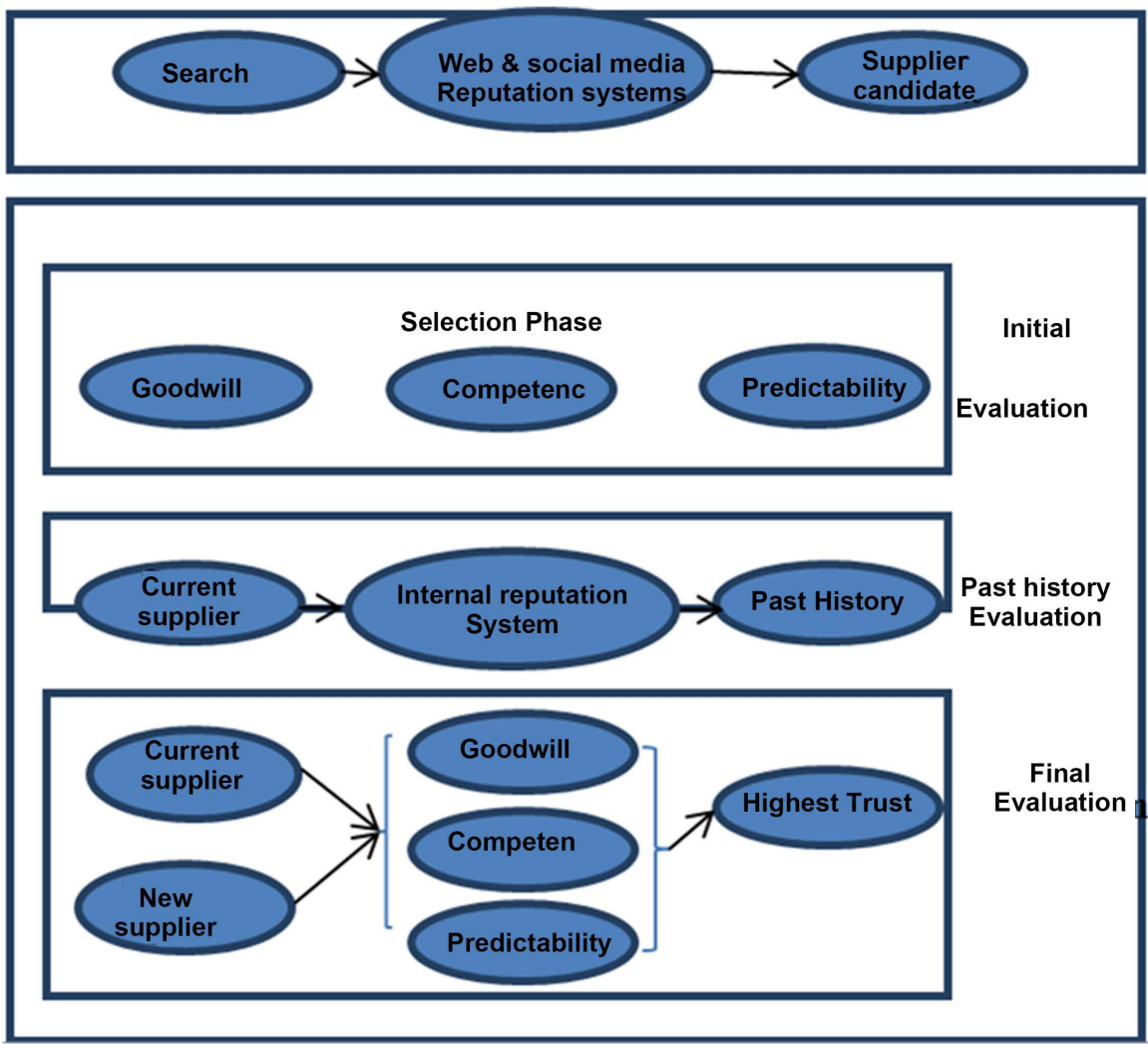

Figure 6. Reputation-based model for selecting trusted partners.

The supplier selection phase includes three steps. In the initial evaluation step the new suppliers will be ranked based on the level of goodwill, competence and predictability trust. The current suppliers are not included in this step. In the past history evaluation step, the current suppliers are evaluated based on the internal reputation system. The previous performance of current suppliers in this step can either reinforce or destroy goodwill, competence and predictability trust. In the final evaluation step, all possible candidates will be ranked based on their level of goodwill, competence and predictability trust. In the end, the supplier with the highest level of goodwill, competence and predictability trust will be selected as a trusted supplier.

\section{Conclusions}

This dissertation attempts to find out the role of reputation systems and social media in selecting global suppliers. In order to address this issue, two companies from different industries and different countries were selected. This selection also could help to better understand the usage of reputation systems in developing and developed countries. The empirical data from these cases were gathered in accordance with the Reputation-Based model for selecting trusted partners offered by [16].

The research has shown that in contrast to the framework offered, both companies relied on reputation systems for searching their suppliers. This issue also 
could highlight the importance of trust in the global supply chain. In fact, both companies where direct experience was absent relied on the reputation of the suppliers based on the experiences of the others. The research has also shown the importance of goodwill, competence and predictability trust in selecting the candidate suppliers.

The research has also shown the importance of past history to the re-selection of suppliers. Both cases had their own reputation systems. The Rare Pink reputation system was based on customer feedback, whereas IDACO reputation system was based on the ERP system. The findings indicate that past history can either reinforce or destroy goodwill, competence and predictability trust. The research also has shown that the reputation of a current supplier from foreign reputation systems might be ignored in the existence of direct experience.

The use of social media as complementary tools for web reputation systems has been discussed. The findings indicate that the lack of trusted reputation systems and the scope of project social media can also be used to provide further trust for the selection of trusted suppliers. In this research, it has been shown that as Rare Pink had trust in those web reputation systems, it did not leverage any social media. The research has proposed the amended framework for selecting trusted suppliers. In the amended framework, in both the supplier discovery phase and the supplier selection phase reputation systems have been used. While in the supplier selection phase, the companies will rely on foreign reputation systems and/or social media; in the supplier selection phase they will rely on their own internal reputation systems to evaluate their suppliers and identify the supplier with the highest level of trust.

\section{References}

[1] Johnson, M.E. (2006) Supply Chain Management: Technology, Globalization, and Policy at a Crossroads. Interfaces, 36, 191-193. https://doi.org/10.1287/inte.1060.0214

[2] Hu, J. and Haddud, A. (2017) Exploring the Impact of Globalization and Technology on Supply Chain Management: A Case of International E-Commerce Business. International Journal of Operations Research and Information Systems (IJORIS), 8 , 1-22. https://doi.org/10.4018/IJORIS.2017100101

[3] Daugherty, P.J., Richey, R.G., Roath, A.S., Min, S., Chen, H., Arndt, A.D. and Genchev, S.E. (2006) Is Collaboration Paying Off for Firms? Business Horizons, 49, 61-70. https://doi.org/10.1016/j.bushor.2005.06.002

[4] Centeno, R., da Silva, V.T. and Hermoso, R. (2009) Reputation Model for Organisational Supply Chain Formation. Proceedings of the 6 th Conference on Autonomous Agents and Multiagent Systems, 9, 33-48. http://cabrillo.lsi.uned.es/ rcenteno/files/papers/coin-aamas09.pdf

[5] Vargo, S.L. (2008) Customer Integration and Value Creation. Journal of Service Research, 11, 211-215. https://doi.org/10.1177/1094670508324260

[6] Tan, K.C. (2001) A Framework of Supply Chain Management Literature. European Journal of Purchasing \& Supply Management, 7, 39-48. https://doi.org/10.1016/S0969-7012(00)00020-4 
[7] Stock, J. and Boyer, S. (2009) Developing a Consensus Definition of Supply Chain Management: A Qualitative Study. International Journal of Physical Distribution \& Logistics Management, 39, 690-711. https://doi.org/10.1108/09600030910996323

[8] Lee, Y.H., Jeong, C.S. and Moon, C. (2002) Advanced Planning and Scheduling with Outsourcing in Manufacturing Supply Chain. Computers \& Industrial Engineering, 43, 351-374. https://doi.org/10.1016/S0360-8352(02)00079-7

[9] Williamson, O.E. (2008) Outsourcing: Transaction Cost Economics and Supply Chain Management. Journal of Supply Chain Management, 44, 5-16. https://doi.org/10.1111/j.1745-493X.2008.00051.x

[10] Narasimhan, R. and Jayaram, J. (1998) Causal Linkages in Supply Chain Management: An Exploratory Study of North American Manufacturing Firms. Decision Sciences, 29, 579-605. https://doi.org/10.1111/j.1540-5915.1998.tb01355.x

[11] Perry, C. (1997) Outsourcing and Union Power. Journal of Labor Research, 18, 521-534. https://doi.org/10.1007/s12122-997-1020-9

[12] Araz, C., et al. (2007) An Integrated Multicriteria Decision-Making Methodology for Outsourcing Management. Computers \& Operations Research, 34, 3738-3756. https://doi.org/10.1016/j.cor.2006.01.014

[13] Fouliras, P. (2011) A Novel Reputation-Based Model for E-Commerce. Operational Research, 3, 1-26.

[14] United Nations (2010) Information Economy Report 2010: ICT Use for Development. http://www.unctad.org/en/docs/ier2010_embargo2010_en.pdf

[15] European Union Competition Car Sector: Jaguar and Land Rover: The Mess in Online Outsourcing.

https://www.reuters.com/article/us-jaguarlandrover-tech-europe/jaguar-land-roverwarns-brexit-deterring-suppliers-eu-workers-idUSKCN1BI1WH

[16] Chen, L.H. and Lin, W.T. (2009) A Reputation-Based Model for Selecting Collaborative Partners with High Level of Initial Trust. Contemporary Management Research, 5, 125-146. https://doi.org/10.7903/cmr.1129

[17] Handfield, R.B. and Nicholas Jr., E.L. (2002) Supply Chain Redesign: Converting Your Supply Chain into Integrated Value Systems. Financial Prentice Hall, New York.

[18] Stadtler, H. (2015) Supply Chain Management: An Overview. In: Supply Chain Management and Advanced Planning, Springer, Berlin, Heidelberg, 3-28. https://doi.org/10.1007/978-3-642-55309-7_1

[19] Optirisk Sytems (2008) Supply Chain Planning and Management. White Paper Series: OPT 003. http://www.optirisk-systems.com/publications.asp

[20] Stern, A., El-Ansary, I. and Coughlan, A. (1996) Marketing Channel. 5th Edition, Prentice Hall, Englewood Cliffs.

[21] Mentzer, J.T. (1999) Supplier Partnering. In: Sheth, J.N. and Parvatiyar, A., Eds., In: Handbook of Relationship Marketing, Sage Publications, Inc., Thousand Oaks, 457-477.

[22] Tian, J. and Tianfield, H. (2007) Multi-Agent Based Dynamic Supply Chain Formation in Semimonopolised Circumstance. In: Advanced Intelligent Computing Theories and Applications. With Aspects of Theoretical and Methodological Issues, Springer-Verlag, Vol. 46, 179-189.

[23] Norman, T.J., Preece, A., Chalmers, S., Jennings, N.R., Luck, M., Dang, V.D., et al. (2004) Agent-Based Formation of Virtual Organisations. Knowledge-Based Systems, 17, 103-111. https://doi.org/10.1016/j.knosys.2004.03.005 
[24] Kathawala, Y., Zhang, R. and Shao, J. (2005) Global Outsourcing and Its Impacts on Organisations: Problems and Issues. International Journal of Services and Operations Management (IJSOM), 1, 185-202. https://doi.org/10.1504/IJSOM.2005.006496

[25] Lonsdale, C. and Cox, A. (2000) The Historical Development of Outsourcing: The Latest Fad? Industrial Management \& Data Systems, 100, 444-450. https://doi.org/10.1108/02635570010358384

[26] Lacity, M. and Hirschheim, R. (1993) Information Systems Outsourcing-Myths, Metaphors and Realities. Wiley.

[27] Oza, N. (2006) An Empirical Evaluation of Client-Vendor Relationship in Indian Software Outsourcing Companies. Ph.D. Hertfordshire University.

[28] Hendry, D.F. (1995) Economic Forecasting. Cambridge University Press, Cambridge.

[29] Drezner, D.W. (2004) The Outsourcing Bogeyman, Foreign Affairs. http://www.foreignaffairs.com/articles/59889/daniel-w-drezner/the-outsourcing-bo geyman

[30] Clark, T.D., Zmud, R.W. and McCray, G.E. (1995) The Outsourcing of Information Services: Transforming the Nature.

[31] Everest Group (2012) Procurement Outsourcing (PO) Annual Report 2012: The PO Market-Steadily Marching Forward. https://research.everestgrp.com/Product/11703

[32] Agerfalk, P.J. and Fitzgerald, B. (2008) Outsourcing to an Unknown Workforce: Exploring Open Sourcing as a Global Sourcing Strategy. MIS Quarterly, 32, 385-409. https://doi.org/10.2307/25148845

[33] Mclennan, B. (2011) Discovering the Value of Supply Chain Outsourcing. Moduslink Global Solution. http://media.cygnus.com/files/cygnus/whitepaper

[34] Liu, Z. and Nagurney, A. (2011) Supply Chain Networks with Global Outsourcing and Quick-Response Production under Demand and Cost Uncertainty. Annals of Operations Research.

[35] Willcocks, L.P., Griffiths, C. and Kotlarsky, J. (2009) Beyond BRIC Offshoring in Non-BRIC Countries: Egypt-A New Growth Market. London School of Economics.

[36] Meixell, M.J. and Gargeya, V.B. (2005) Global Supply Chain Design: A Literature Review and Critique. Transportation Research Part E: Logistics and Transportation Review, 41, 531-550. https://doi.org/10.1016/j.tre.2005.06.003

[37] PWC (2013) Next-Generation Supply Chains Efficient, Fast and Tailored. http://www.pwc.com/gx/en/consulting-services/supply-chain/global-supply-chain-s urvey/assets/pwc-global-supply-chain-survey-2013.pdf

[38] Mentzer, J.T., DeWitt, W., Keebler, J.S., Min, S., Nix, N.W., Smith, C.D. and Zacharia, Z.G. (2001) Defining Supply Chain Management. Journal of Business Logistics, 22, 1-25. https://doi.org/10.1002/j.2158-1592.2001.tb00001.x

[39] Everest Group (2013) Supply Chain Management (SCM) BPO-Beyond Procurement Outsourcing (PO). https://research.everestgrp.com/Product/12032

[40] Hugos, M.H. (2018) Essentials of Supply Chain Management. John Wiley \& Sons.

[41] Luo, W., Shi, Y. and Venkatesh, V.G. (2018) Exploring the Factors of Achieving Supply Chain Excellence: A New Zealand Perspective. Production Planning \& Control, 1-13. 
[42] Weber, C.A., Current, J. and Benton, W.C. (1991) Vendor Selection Criteria and Methods. European Journal of Operational Research, 50, 2-18. https://doi.org/10.1016/0377-2217(91)90033-R

[43] Weber, C.A., Current, J. and Desai, A. (1998) Non-Cooperative Negotiation Strategies for Vendor Selection. European Journal of Operational Research, 108, 208-223. https://doi.org/10.1016/S0377-2217(97)00131-8

[44] Dickson, G.W. (1996) An Analysis of Vendor Selection Systems and Decisions. Journal of Purchasing, 2, 5-17. https://doi.org/10.1111/j.1745-493X.1966.tb00818.x

[45] Bei, W., Wang, S. and Hu, J. (2006) An Analysis of Supplier Selection in Manufacturing Supply Chain Management. International Conference on Service Systems and Service Management, 2, 1439-1444. https://doi.org/10.1109/ICSSSM.2006.320724

[46] Wind, Y., Green, P. and Robinson, P.J. (1968) The Determinants of Vendor Selection: The Evaluation Approach. Journal of purchasing, 34, 29-42.

[47] Lehmann, D.R. and O'Shaughnessy, J. (1974) Decision Criteria Used in Buying Different Categories of Products. Journal to Marketing, 102, 36-42.

https://doi.org/10.2307/1250195

[48] Perreault, W.D. and Russ, F.A. (1976) Physical Distribution Service in Industrial Purchase Decisions. Journal of Marketing, 45, 3-10.

https://doi.org/10.2307/1251000

[49] Abratt, R. (1986) Industrial Buying in High-Tech Markets. Industrial Marketing Management, 15, 293-298. https://doi.org/10.1016/0019-8501(86)90021-0

[50] Billesbach, T.J., Harrison, A. and Croom-Morgan, S. (1991) Supplier Performance Measures and Practices in JIT Companies in the US and the UK. International Journal of Purchasing and Materials Management, 27, 24-28.

[51] Choi, T. and Hartley, J. (1996) An Exploration of Supplier Selection Practices across the Supply Chain. Journal of Operations Management, 12, 333-343. https://doi.org/10.1016/S0272-6963(96)00091-5

[52] Verma, R. and Puliman, E.A. (1998) An Analysis of the Supplier Selection Process. Omega, International Journal of Management Science, 26, 739-750.

[53] Yahya, S. and Kingsman, B. (1999) Vendor Rating for an Entrepreneur Development Programme: A Case Study Using the Analytic Hierarchy Process Method. Journal of the Operational Research Society, 50, 916-930. https://doi.org/10.1057/palgrave.jors.2600797

[54] Petroni, A. and Braglia, M. (2000) Vendor Selection Using Principal Component Analysis. The Journal of Supply Chain Management: A Global Review of Purchasing and Supply, 36, 63-69.

[55] De Boer, L. and van der Wegen, L. (2003) Practice and Promise of Formal Supplier Selection: A Case Study of Four Empirical Cases. Journal of Purchasing \& Supply Management, 32, 109-118. https://doi.org/10.1016/S1478-4092(03)00018-9

[56] Cheraghi, S., Dadashzadeh, M. and Subramanian, M. (2004) Critical Success Factors for Supplier Selection: An Update. Journal of Applied Business Research, 20, 91-108.

[57] Shil, N.C. (2009) A Case on Vendor Selection Methodology: An Integrated Approach. Journal of Transport and Supply Chain Management, 80-95.

[58] Ho, W., Xu, X. and Dey, P.K. (2010) Multi-Criteria Decision Making Approaches for Supplier Evaluation and Selection: A Literature Review. European Journal of Operational Research, 202, 16-24. https://doi.org/10.1016/j.ejor.2009.05.009 
[59] Izadikhah, M. (2012) Group Decision-Making Process for Supplier Selection with TOPSIS Method under Interval-Valued Intuitionistic Fuzzy Numbers. Advances in Fuzzy Systems. https://doi.org/10.1155/2012/407942

[60] E-commerce Technology (2005) E-Commerce Application. http://ecommercetechnology.org/english/data/70.htm

[61] Brunelli, M. (2000) Online Auctions Save Millions for Quaker Oats and Smith Kline Beecham. Purchasing, 128, S22.

[62] Resnick, P., Seckhauser, R., Friedman, E. and Kuwabara, K. (2000) Reputation Systems. Communication of the ACM, 43, 45-48. https://doi.org/10.1145/355112.355122

[63] Kwon, I.W. and Suh, G.T. (2004) Factors Affecting the Level of Trust and Commitment in Supply Chain Relationships. The Journal of Supply Chain Management, 40, 4-14. https://doi.org/10.1111/j.1745-493X.2004.tb00165.x

[64] Jøsang, A., Ismail, R., et al. (2007) A Survey of Trust and Reputation Systems for Online Service Provision. Decision Support Systems, 43, 618-644. https://doi.org/10.1016/j.dss.2005.05.019

[65] Dueze, M. (2009) The Media Logic of Media Work. Journal of Media Sociology, 1, $22-40$.

[66] Qualman, E. (2009) Socialnomics: How Social Media Transforms the Way We Live and Do Business. Wiley, Hoboken.

[67] Kaplan, A. and Haenlein, M. (2010) Users of the World, Unite! The Challenges and Opportunities of Social Media. Business Horizons, 53, 59-68. https://doi.org/10.1016/j.bushor.2009.09.003

[68] Cook, N. (2008) Enterprise 2.0: How Social Software Will Change the Future of Work. Gower Publishing: Surrey.

[69] Rheingold, H. (1994) A Slice of Life in My Virtual Community. In Harasim, L.M., Ed., Global Networks. Computers and International Communication, MIT Press, Cambridge, MA.

[70] Whitaker, R. (1997) Managing Context in Enterprise Knowledge Processes. In: The Strategic Management of Intellectual Capital, 73-86.

[71] Markus, U. (2002) Characterizing the Virtual Community. http://www.sapdesignguild.org/editions/edition5/communities.asp

[72] Guo, J., Chen, R. and Tsai, J.J. (2017) A Survey of Trust Computation Models for service Management in Internet of Things Systems. Computer Communications, 97, 1-14.

[73] Kasper-Fuechrer, E.C. and Ashkanasy, N.M. (2001) Communicating Trustworthiness and Building Trust in Interorganizational Virtual Organizations. Journal of Management, 27, 235-254. https://doi.org/10.1177/014920630102700302

[74] Gambetta, D. (1990) Can We Trust Trust? In: Gambetta, D., Ed., Trust: Making and Breaking Cooperative Relations, Basil Blackwell, Oxford, 213-238.

[75] McKnight, D.H., Chervany, N.L. and Cummings, L.L. (1996) Trust Formation in New Organizational Relationships. Management Information Systems Research Center, Curtis L. Carlson School of Management, University of Minnesota.

[76] Ratnasingam, P. (2005) Trust in Inter-Organizational Exchanges: A Case Study in Business to Business Electronic Commerce. Decision Support Systems, 39, 525-544. https://doi.org/10.1016/j.dss.2003.12.005

[77] Koufaris, M. and Hampton-Sosa, W. (2004) The Development of Initial Trust in an 
Online Company by New Customers. Information \& Management, 41, 377-397. https://doi.org/10.1016/j.im.2003.08.004

[78] Artz, D. and Gil, Y. (2007) A Survey of Trust in Computer Science and the Semantic Web. Web Semantics, 5, 58-71. https://doi.org/10.1016/j.websem.2007.03.002

[79] Wang, Y. and Vassileva, J. (2007) Toward Trust and Reputation Based Web Service Selection: A Survey, Int'l Trans. Systems Science and Applications, 3, 118-132.

[80] Heylighen, F. (2017) Towards an Intelligent Network for Matching Offer and Demand: From the Sharing Economy to the Global Brain. Technological Forecasting and Social Change, 114, 74-85.

[81] e-Bay (2013) How Feedbacks Work. http://pages.ebay.com/help/feedback/howitworks.html

[82] Ubois, J. (2003) Online Reputation Systems. Release 1.0, 21(9). http://cdn.oreillystatic.com/radar/r1/10-03.pdf

[83] Ehsaei, F. (2012) Acceptance of Feedbacks in Reputation Systems: The Role of Online Social Interactions. Information Management and Business Review, 4, 391-401.

[84] Li, Z. and Shen, H. (2009) Analysis of a Hybrid Reputation Management System for Mobile ad Hoc Networks. Proceedings of 18 th International Conference on Computer Communications and Networks, 2009. ICCCN2009. IEEE, 1-6. https://doi.org/10.1109/ICCCN.2009.5235332

[85] Govindan, K., Rajendran, S., Sarkis, J. and Murugesan, P. (2015) Multi Criteria Decision Making Approaches for Green Supplier Evaluation and Selection: A Literature Review. Journal of Cleaner Production, 98, 66-83. https://doi.org/10.1016/j.jclepro.2013.06.046

[86] Hashemi, S.H., Karimi, A. and Tavana, M. (2015) An Integrated Green Supplier Selection Approach with Analytic Network Process and Improved Grey Relational Analysis. International Journal of Production Economics, 159, 178-191. https://doi.org/10.1016/j.ijpe.2014.09.027

[87] Yin, R.K. (2009) Case Study Research: Design and Methods. Sage Publications, Los Angeles, Calif.

[88] Saunders, M., Lewis, P. and Thornhill, A. (2009) Research Methods for Business Students. Pearson Education, Essex.

[89] Blumberg, B. (2008) Business Research Methods. McGraw-Hill, Berkshire. 